\title{
Balkanologie
}

Balkanologie Revue d'études pluridisciplinaires

Vol. V, no 1-2 | 2001

Volume V Numéro 1-2

\section{Croatian Catholic Church Imagines the Nation}

Glas koncila and the Croatian National Question, 1985 - 1990

\section{Maja Brkljačić}

\section{CpenEdition}

\section{Journals}

Electronic version

URL: http://journals.openedition.org/balkanologie/668

DOI: 10.4000/balkanologie.668

ISSN: 1965-0582

\section{Publisher}

Association française d'études sur les Balkans (Afebalk)

\section{Printed version}

Date of publication: 31 December 2001

ISSN: 1279-7952

\section{Electronic reference}

Maja Brkljačić, «Croatian Catholic Church Imagines the Nation », Balkanologie [Online], Vol. V, n 1-2 I

2001, Online since 31 May 2008, connection on 17 December 2020. URL : http://

journals.openedition.org/balkanologie/668; DOI : https://doi.org/10.4000/balkanologie.668

This text was automatically generated on 17 December 2020.

(c) Tous droits réservés 


\title{
Croatian Catholic Church Imagines the Nation
}

\author{
Glas koncila and the Croatian National Question, 1985 - 1990
}

\section{Maja Brkljačić}

1 On May 30, 1990, the first Croatian post-communist multi-party Parliament was constituted, after the free election which took place only a few days earlier and which brought a clear victory to the Croatian Democratic Union (CDU) and its head, Franjo Tudjman. On that day, the Croatian parliament proclaimed Tudjman the president of the Republic of Croatia which was still at that time one of the constitutive republics of the Yugoslav federation. After the first multi-party session of the Parliament, a grand popular festivity was organised on the main city-square in Zagreb, the Square of Banus Josip Jelačić. The leading press-organ of the Croatian Catholic Church, Glas Koncila, brought the following reportage from the event. Once the session of the Parliament was over, «Franjo Tudjman walked the way to the Jelačić square ». On the way, he passed through Kamenita vrata, where « he kneeled before the altar of the Holy Mother », « lit a grand, richly decorated celebratory candle ", " put his hands together and whispered a prayer, looking at the statue of the Holy Mother ». Then he continued his walk to the Jelačić square, where he climbed the pre-arranged stage. From the other side, there came to the square the Cardinal and the archbishop of Zagreb, Franjo Kuharić, and joined Tudjman on the stage. The stage was already surrounded by a turbulent and cheering crowd. There was quite a number of people on the stage. The foreground was occupied by the two leaders, the secular and the spiritual. Franjo Tudjman and Franjo Kuharic faced each other, and between them, in the centre of the picture, there was a baby-cradle ${ }^{1}$. The scene was, indeed, memorable: the modern Croatian pater patriae, his partner Ecclesia Croatica, and the imagined infant in the cradle. Thousands of spectators came to bow before them. 


\section{Pre-history of a Relationship}

2 Much has been written on the troubled relationship between church and state under communism, as well as on the communist politics and policies towards religion in general. This is certainly true for the Yugoslav case which was an interesting research problem due to the fact that the federalization of the religious policy apparatus and the legal structure produced a federalization of religious policy ${ }^{2}$, which meant that the eight constituent federal units could preserve different religious policies towards their respective churches. Overall, the attitude towards religious institutions in the communist Yugoslavia could be described as fairly liberal (for communist circumstances, of course), even though far from ideal. In the case of the Croatian Catholic Church, this meant that, like in Czechoslovakia, Poland, Hungary and Romania, the Communist party (unsuccessfully) tried to persuade it to break off its ties with the Vatican and institutionalise itself as a national church. The highest church official in Croatia, Cardinal Alojzije Stepinac, was imprisoned 1946 and died in the house-arrest 1960. Most of the property of the Church was nationalised, and some catholic priests were harassed and arrested. It happened from time to time that church newsletters and periodicals were banned. When in January 1983, Dominican Frano Prčela vehemently criticised in a Sunday sermon in Split a student newspaper article that portrayed the Virgin Mary as taking birth control pills and Christ as a hashish addict, he was arrested by the security forces for violating freedom of the press ${ }^{3}$. Nevertheless, it cannot be denied that the so-called liberal sixties definitively paved the way for a more or less peaceful coexistence of the Church and the state. The dialogue with the Church was opened on the level of Marxist sociologists and philosophers. The official party discourse changed from the dogmatic approach which stated that «religious institutions and organizations endeavor to hold people in subjection $»^{4}$ to assertions such as "Religious conviction is not an absolute obstacle to participation in the building of socialism $»^{5}$, or " in the political emancipation of man from religion, the socialist state does not seek the abolition of religion $»^{6}$.

Clearly, what was at stake in the battle between the state and the church were people's loyalties: both institutions were hunting for human souls. In Croatia, the Church enjoyed a considerable advantage, as the links connecting it to the population were strong and old. In 1972, 93,4 percent of the population of the Zagreb region declared themselves to be members of the Roman Catholic Church; ranks of the Communist Party were never that crowded. In the same year, only 5,7 percent said they were atheists. The survey showed that 58,8 percent of the women and 43,6 percent of the men were practicing believers ${ }^{7}$. Another survey from 1979 revealed that almost a 100 percent of rural children in Croatia attended regularly religious instruction, while the percentage in the cities shifted between 40 and $50^{8}$.

These high numbers testify to the fact that the allegiance to the Croatian Catholic Church was strong and its influence important. This makes studying the attitudes and position of the Church under communism an even more interesting task. The purpose of this essay is to try to contribute to this area of research. More specifically, the paper will address one principal issue: writing of the most influential and widely-spread press-organ of the Croatian Catholic Church, Glas Koncila, in the last five years of communism. ${ }^{9}$ Since the collapse of communism was in Yugoslavia overshadowed by the Serbo-Croatian war, the essay will concentrate chiefly on the relation and attitude of 
the Church towards the Croatian and Serbian nations as presented by Glas Koncila. In other words, I will point to some possible explanations to the troubling dilemma : why was the highest representative of the Croatian catholic clergy joining hands in public in 1990 with the Croatian secular leader, Franjo Tudjman, and how did the Croatian Catholic Church help in bringing to the world the imagined infant in the cradle that Cardinal Kuharić was standing next to. In order to answer this question, I will follow changes in writing of Glas Koncila from 1985 until 1990, focusing on the analysis of discourse, modes of representation, and topics discussed ${ }^{10}$.

\section{Merging the Church and the Nation}

5 The first feature one notices when reading issues of Glas Koncila published in 1985 is that its relation to the Croatian nation is rather shy, or, even better, entirely indirect. The expression "Croat » as a noun or "Croatian» as an adjective appears only very rarely, and even when we do find it, it is almost always firmly connected to a very specific context. The noun « Croat» (or, its plural form, «Croats ») surfaces principally on two occasions: firstly, in articles discussing historical topics. For example, in January 1985 Glas Koncila started a series of articles entitled «Beginnings of art-music among Croats ${ }^{11}$, and from September of the same year we read again a series of contributions about "Croats at the University of Paris in Middle Ages " ${ }^{12}$. Second type of articles providing a context for the noun « Croat » relates to commentaries about life of the Croatian diaspora - Croats living outside of Croatia and Yugoslavia. Again, in an issue from January 1985 there is a report about Marijana Koznjak, a Croat who was chosen for miss Australia ${ }^{13}$, and not even a month later we read about a deceased Croat, priest from Burgendland ${ }^{14}$. The term "Croatian" as an adjective is hardly ever used. It can be located again in a contribution about a historical topic : a reportage from Kastav in Istria, a place where "Croatian language" has always been spoken ${ }^{15}$. Once the temporal plane changes from the past into the present, we notice a difference in discourse. In an article about the influx of migrants to the suburbs of Zagreb, only regional designations are to be found: not Croats are mentioned, but Ličani (people from the region of Lika in Croatia), Bošniaks and people from Herzegovina ${ }^{16}$.

6 This did not mean that Glas Koncila left in 1985 any doubt as to the audience it was addressing, even though the crucial adjective describing belonging was missing. Hence, even though the noun "homeland" in Glas Koncila always lacks the signifier determining whose homeland (i.e. Yugoslavia or Croatia), connotative analysis showed that homeland for Glas Koncila meant only Croatia ${ }^{17}$. Equally, authors in Glas Koncila preferred talking simply about « mother tongue » without specifying exactly which one they had in mind. In Yugoslavia in the eighties this was far from clear: the official language was called "Serbo-Croatian", "Croato-Serbian", "Serbian or Croatian", "Croatian or Serbian", and the difference in the signifier meant the real difference in the signified. For Glas Koncila, however, "mother tongue ", even though not clearly determined, was only Croatian language ${ }^{18}$.

7 The importance of the Croatian Catholic Church for the Croatian nation was in 1985 a topic that was discussed in Glas Koncila only by Leserbriefe. It took three years for this topic to be transferred into the official discourse of the highest Church officials. In 1985 only readers of Glas Koncila were those who maintained that "Catholic priests were crucial for the linguistical preservation of our national being ${ }^{19}$. The continuation of 
this debate can be followed in 1988, when Cardinal Kuharic asserted that «the Croatian Catholic Church was rooted into the consciousness of the Croatian Volk for over thirteen centuries $»^{20}$. In 1985 such open statements could have been made only in the context of the stories about the Croatian diaspora. Only for them it was possible to maintain that " to be Croat and to be Catholic goes together $"^{21}$. Three years later, Glas Koncila strengthened its efforts at fortifying historical connections between the Croatian Catholic Church (and Catholicism in general) and the Croatian national consciousness. Apart from the mentioned Cardinal's declaration, we read in 1988 about bishops who, like Ivan Antunović, worked in the last century on the national revival among Croats $^{22}$, or about Juraj Haulik, first Croatian archbishop and Cardinal, who was also " protector of Croatian national rights ${ }^{23}$. Quite appropriately, in May 1988, Glas Koncila starts a series of articles entitled "Catholic Church and Croatian language » which aimed to demonstrate the struggle of the Croatian Catholic Church to preserve the Croatian language ${ }^{24}$.

8 Another track of the same process can be observed in attempts by Glas Koncila to conjoin important figures from the Croatian national pantheon with Catholicism. Two Croatian noblemen from the seventeenth century who were decapitated by the Habsburgs, Nikola Zrinski and Fran Krsto Frankopan, are turned into "martyrs who grow out of the Christian roots $»^{25}$. Equally, the most important Croatian hero from the twentieth century, Stjepan Radić, who was killed by Puniša Račić, a militant Serbian nationalist, in Belgrade 1928, is portrayed by Glas Koncila as a serious and devoted Catholic ${ }^{26}$. The real issue at stake behind all these undertakings was revealed in an interview with Franc Perko, archbishop of Belgrade, who in February 1988 held that "Croatian Catholic Church is not enough national » and that "Church should not be so supranational that it disrespects its belonging to the nation $»^{27}$. Such statements could not be in the same year officially made by someone who sat in Croatia, whereas Perko from Belgrade could be more open and direct ${ }^{28}$. It took another two years for Glas Koncila to complete the relationship between the Church and the nation : in a text with a subtitle "where all that was Croatian has for centuries been suffocated and persecuted, the most diverse artistic and cultural valuables were created", we read that in Zadar, " as in other Croatian areas, the preserved cultural national treasure is associated with the Catholic Church $»^{29}$. The relationship is underlined by a story about the Catholic Church in Herzegovina, according to which the Church prevented Croats to rebel against the imposed Cyrillic alphabet by giving Croatian children an opportunity to learn the Latin alphabet in classes of the Catholic religious instruction ${ }^{30}$.

We could describe this process as renationalisation of the Croatian Catholic Church. It developed in two directions: Croatisation of the Church and Catholisation of the nation. In the earlier periods, before 1985, dominant themes discussed by Glas Koncila were human rights, struggle against atheism, anti-abortion legislature. The process of renationalisation was at the beginning slow and very careful. One possible answer why this was difficult and complex could perhaps be found in the case of Alojzije Stepinac, Cardinal and Archbishop of Zagreb, who was prosecuted by the Communist authorities in the aftermath of the Second World War for collaboration with the fascist Ustasha authorities. The reports in Glas Koncila from his annual concelebrations, by which the Church celebrated the anniversary of his death, show transparently that Stepinac was an open wound of the Croatian Catholic Church. Changes in his public image were directly related to the renationalisation of the whole institution. The purification of Stepinac's figure had several stages. In 1985, he was celebrated by Glas Koncila as 
"protector of the poor and oppressed " and as «the bravest bishop in Europe » in his time. In order to prove this point, Cardinal Kuharić quoted during the concelebration a witness account of an anonymous Serbian intellectual from Zagreb ${ }^{31}$, for this source offered a double legitimisation: Serb and intellectual defending Stepinac. At that moment, there was not a word spoken about Stepinac in connection with the Croatian nation. As an article, quoted from a contemporary youth magazine, testified, Stepinac was declared to be persecuted " because he protected the freedom of the Church ${ }^{32}$. Next to Stepinac's name, we find no mentioning of Croats. Three years later, Cardinal Kuharić briefly alluded for the same anniversary that Stepinac very much liked the inscription beneath the statue of the Holy Mother in Remete (close to Zagreb) which read «Advocata Croatiae - Fidelissima Mater $»^{33}$. Finally, in 1990 we read Stepinac's own testimony from the trial, in which he stated that «the Croatian people chose the Croatian state by plebiscite, and I would have been unworthy, had I not felt the pulse of the Croatian nation that was a slave in the former Yugoslavia ». The testimony was published in Glas Koncila under the title : « For my conviction, I am ready to die $»^{34}$. With this, a long path has been walked from Stepinac who was defended by a Serbian intellectual, to Stepinac who dies for his conviction that the Croatian nation was a slave in the Yugoslav Kingdom, and who therefore does not any longer need any Serbs as an apology and explanation.

\section{World War Two Reappraised}

10 It should also be mentioned that the relation of Glas Koncila towards the troubling heritage of the Second World War is problematic and at times ambivalent. It is evident that Glas Koncila strove to detach the Croatian Catholic Church from the Ustashas. However, in spite of the condemnation of the war crimes, there is no awareness about the historical responsibility for the crimes. This becomes increasingly problematic in the context in which the continuity of the nation is insisted upon. Nation is, perhaps, a continuity, but, as we read in Glas Koncila in October 1988, children are not responsible for sins of their fathers because to sin is human, and « human is personal $»^{35}$.

11 And yet, even though children are not responsible for what their fathers did, it was important for Glas Koncila to work to improve the image of the Croatian nation for the period of the Second World War. In May 1988, it is claimed that, statistically speaking,

Croats are the only nation in Yugoslavia which was reduced in number in the course of World War Two. War casualties decreased the expected growth of other Yugoslav nations, whereas they reduced Croats in their existing numbers. The comparison of data for 1931 and 1948 shows that the number of Croats in that period declined for 9,2 percent, while the number of Serbs grew for 0,6 percent, Slovenes for 0,9 percent, etc.

12 The numbers were supposed to show that « Croatian Catholics are not the way they are presented today $»^{36}$.

13 Simultaneously, Glas Koncila worked to prove that the war record of the Croatian Catholic Church is no worse than the record of the Serbian Orthodox Church. By making these parallels, Glas Koncila tried to normalise or relativise the difficult historical experience of the Second World War. While it was not possible to deny that there were forced conversions from Orthodoxy into Catholicism in WWII in Croatia, Glas Koncila immediately adds that there were «even more numerous forced 
conversions of Catholics into Orthodoxy in Ukraine, Romania, Bulgaria and Slovakia after the war ". And it continues that the Catholic Church condemned and distanced itself from such practices, while one yet has to hope that «Orthodox consciousness matures and publicly declares its position $\|^{37}$. Such paradigmatic reasoning « we-they ", in which the other side is blamed for what was otherwise considered to be "the Croatian sin ", can be traced throughout 1990, too. In March, a series of articles was started about the attitude and behaviour of the Serbian Orthodox Church in the Second World War which began with an essay "Declarations of loyalty to occupational authorities » allegedly issued by the Serbian Orthodox $\mathrm{Church}^{38}$. Further sequels aimed to prove that the highest representatives of the Serbian Orthodox Church not only failed to resist the German forces but even helped them to maintain the discipline on the occupied territory. Later that year, another series of articles was launched under the title « "Jewish question" in World War Two in Serbia ». It contained articles about the persecution of the Jews in Serbia, their killings and the confiscation of their properties $^{39}$. As a consequence of these efforts, we find in Glas Koncila a letter by an anonymous reader holding that «Croats were declared in Yugoslavia to be genocidal for political reasons -- in order to enable Serbian expansion -- and for economic reasons -- in order to enforce on Croats paying of the war retribution -- even though Croats were a nation which suffered most during the war and after it $»^{40}$.

\section{" The urge to be Croats ... »}

14 Gradual but with time more open discussion of issues concerning the Croatian nation paved the way for a following, symptomatic letter by a reader of Glas Koncila, printed shortly before the first multi-party elections in Croatia, when the political situation already became rather sensitive. The letter was written by a pupil, seventeen years old, who was assigned by her school-teacher to write an essay entitled « We are first of all humans, and only after that Croats, Serbs ... ». The pupil wrote to Glas Koncila that she was very unhappy and dissatisfied with the designated title of the essay, for «belonging to the species is insufficient. (.....) I want my identity. (.....) In my name and my origins I carry the heritage of centuries. We are Croats. I belong to the Croatian nation $»^{41}$.

The results of the election and the victory of Tudjman's party were then for Glas Koncila no surprise at all. A report commenting the passed election appears under the title " Didn't it have to be this way? ", because " Croats felt before the voting boxes the urge to be first of all Croats, and only after that to think about nuances differentiating political programmes ${ }^{42}$. In the same article, discourse representing Croats as an endangered species in Yugoslavia became officially and openly institutionalised ${ }^{43}$ : " under the successful leadership of the Croatian Democratic Union (CDU), it will be necessary to quit the one-party onemindedness and the unbearable feeling of being endangered under which the Croatian nation suffers $»^{44}$. This feeling, according to Glas Koncila, was not of a recent origin. In August 1990, we read about «the craving of the [Croatian] nation whose name and every sign have been deleted, so it could be defaced and erased from the face of the Earth and buried in history, as a scapegoat, with someone else's sins $»^{45}$. campaign an individual named Boško Čubrilović threatened Tudjman with a gun at a 
gathering in Benkovac, Glas Koncila commented that the event took place « in the tradition of Puniša Račić from $1928 »^{46}$. The invocation of the mythical past time continued. In another article about the alleged Serbian provocation, Glas Koncila asserted that « it is necessary to make evident that this is the same scenario which was at work when Stjepan Radić was murdered, when Catholics and Muslims were exterminated by the Chetniks, and in all post-WWII attempts to blame and persecute the Croatian Catholic Church and the Croatian nation, both of which were declared genocidal $»^{47}$.

For Glas Koncila, the past has never ended ; instead it was transferred into the present, where it was living through its only logical and natural sequels. But this was not the whole pre-history evoked by Glas Koncila. In October 1990, an interview with « the most famous poet of the Croatian diaspora ", Vinko Nikolić, was published under the title « Return from the legend ». In the interview, Glas Koncila forgot to mention that Nikolić was a high-ranking Ustasha officer. Nikolić himself, however, did not forget to offer his interpretation of the events, past and present : «When we used to explain who started conflicts in 1941, people found it hard to believe us. But Knin [centre of the Serbian Krajina] confirms again that they would neither today nor yesterday leave us in peace, so we could develop Croatia into a free and democratic state $»^{48}$. We read thus in Glas Koncila that the fascist Independent State of Croatia wanted to organise itself as a democratic state, but that Serbs obstructed those efforts, a situation which, according to Nikolić, was being repeated at the time of the interview. The stigmatisation of Serbs and Yugoslavia (with which Serbs were identified) became a frequent topic in Glas Koncila. In August 1990 we read under the title "Yugoslavia as a negative experience " that « it could have been clear from the very start that the strongest in Yugoslavia created this state as a chance to uproot Islam and Catholicism, and to introduce throughout the country Islam and Orthodoxy $»^{49}$. Or, that «during the past seven decades, the hate between nations grew ", and that "the Western Catholic part of the state was exhausted; what Turks began, Yugoslavia continued $»^{50}$. This "what» is clearly signified: "the expansion of Serbian territories and of Orthodoxy, because Serbs behave in new regions as conquerors, and the Serbian Orthodox Church strives to serbianise all its believers in Yugoslavia $»^{51}$. With an inescapable comment that the Croatian Catholic Church never did anything similar.

The process of the national re-awakening was rounded up by Glas Koncila in the following way:

a human being cannot be human outside of a community. (.....) Belonging to a nation is a mark of a true human. (.....) [T]o be Croat means to be human in a Croatian way .... no-one is human in any way or in all ways. (.....) Thus, we know that it is highly important that we are Croats - that this is important for the soul and for the body ${ }^{52}$.

\section{Past Suffering Turning Present}

Nevertheless, as Glas Koncila testifies, it was not an easy thing to be Croat. Especially, it was difficult to belong to one Croatian nation. It is not possible at this point to elaborate more on it, but it is known that the experience of the Second World War divided Croatia - two camps, the so-called Ustasha camp and the partisan camp were not the only ones, but they came to the fore most often. The idea of the national reconciliation varied in content, depending on its creators' imagination. In the 
communist Yugoslavia, the official interpretation was that foreign occupiers (Germans and Italians) were to be blamed for all committed evils and crimes; with their elimination, the reason for antagonisms and frictions vanished. It should be said though that Communists were less interested in the idea of the inner-Croatian reunion and more in the Croato-Serbian re-alignment through the idea of brotherhood and unity ${ }^{53}$. There were, however, others with different visions. Former commander of the Ustasha concentration camp Jasenovac, Maks Luburić, who fled the country in 1945, construed the first plan for Croatian national reconciliation on the basis of all Croatian victims. The idea was adopted in emigration by another Croatian migrant, Bruno Busić, and from Busić by Franjo Tudjman; the latter tried to materialise it in the nineties by an attempt to transfer to Jasenovac the bones of Croats who were killed by partisans and to create in Jasenovac a memorial place for all Croats killed by the two totalitarian regimes. To mix thus the bones of the dead in order to reconcile the living. As we read from Glas Koncila, such ideas were not alien to the Croatian Catholic Church either. In April 1990, Glas Koncila invited all interested to attend a celebratory mass for Zrinski and Frankopan which would be "a memorial day for all who died for the Croatian homeland» (ergo, on all sides) $)^{54}$. This somewhat modest plea intensified in the second half of 1990, when a number of cavities was discovered which contained bones of people killed immediately after the Second World War. When a cave known as Jazovka was unveiled, Glas Koncila openly called for « reconciliation through victims $»^{55}$. Finally, in November 1990, a mass was held for «all victims of war and post-war period ». On that occasion, Glas Koncila wrote (under the title « To bury the spirit of war times ») that " the Croatian Catholic Church wanted to return dignity to the countless innocent victims and to call living to reconcile with the God and people ${ }^{56}$. All Croats killed in the period 1941-1990 became thus innocent victims. Accordingly, bishop Djuro Koksa held the celebratory mass on this occasion in Zagreb, during which he compared the history of the Croatian people with the history of the chosen Israeli people and concluded his sermon with a cry: «there are so many tears, so much pain, broken hearts, interrupted lives, abridged hopes, severed branches, murdered fathers and sons, disgraced and humiliated mothers and daughters ..... but we do not want revenge; we want this drama to provoke in us evolution, reconciliation and catharsis $»^{57}$. The Croatian Catholic Church is revealed thus as a strong force that worked to homogenise the nation.

The discourse of suffering and martyrdom was strongly present in Glas Koncila throughout the second half of 1990. In September, a series of articles was initiated under the collective title "Testimonies about sufferings». The first article brought on the same page and in the same red frame two texts. One was about the killing of Milan Sufflay (murdered by Serbian nationalists 1931 in the Yugoslav Kingdom) who "gave his life for homeland Croatia $»^{58}$. The other text, which has nothing in common with Sufflay's story but which nevertheless shares its frame, is illustrated by a photograph of a mutilated dead body which is supposed to be a Catholic priest Zigrović. According to the text, "nothing on the man's body remained intact. The witnesses of the murder remember that the priest was dragged by horses in run, that his torturers cut off his genitals and broke all his bones $»^{59}$. Allegedly, the crime was committed by an anonymous partisan fighter in 1943. The arrangement of the two essentially unrelated stories under the same title of suffering, the photo of the body and textual details, all together aimed to provoke strong emotions in the reader. The equation proposed was 
very simple : Serbs are the same as partisans, and together, they fought against Croats and Croatia.

The series about Croatian sufferings continued further. Its most vivid contribution came in October, in an article about the cave Gluvuša, twenty meters deep, where the bones of the killed around the war and immediately after it were thrown. Glas Koncila does not say who killed those people, but it asserts that the authorities took great precautions to keep possible witnesses away from the cave. In spite of their efforts, some people were able to recount a story about the double death of a young man who

after being stabbed in the throat and thrown in the cave, climbed out of the cave and was killed again. The eye-witness says that he saw wounds made by a knife in the young man's throat. Half-dead and at the end of his strength, the young man entered one house near-by and, pointing with his hands, asked for a glass of water, for he could not speak. As he drank it, the water leaked out of his wound and spilled out on his chest. When one of his executioners found out about the escaped, he tied him up, took away and shot him during the day-light ${ }^{60}$.

Finally, sufferings had to be carried into the present. In November 1990, Antun Grahovar, a priest from the city of Sisak, was murdered. Before the official statement and the police investigation into the circumstances of his death, Glas Koncila printed its own version of the event. It alluded to the ultimate interpretation already in the title, "Who was disturbed by Croatian Catholic priest?", implying thus that he was killed because he was Croatian, plus Catholic, plus priest. Such reading is enhanced by the article which states : "Every crime is preceded by hate. (...) Isn't hate being incited in our region, and especially lately, toward everything that is Catholic and Croatian?». Starting from this, it was only possible to conclude that the killed priest was « a martyr for faith, the Church and for Croatian nation. He is the last among many martyrs who have saturated with their blood our Croatian soil $»^{61}$.

\section{A Meaningful Conclusion?}

On August 18, 1990, Tudjman's party organised and officially institutionalised its sisterparty in Bosnia and Herzegovina. Many Croats from all over BiH took part in the constitutive gathering in Sarajevo that day. Buses with Croats came also from a small Herzegovinian town Bugojno. Glas Koncila describes the fate of the bus from Bugojno as follows. On return, the bus was hit by stones thrown at it by people from Sarajevo. Several windows were broken, and one stone hit a middle-aged woman, Ljuba Turulija, in the head. The bus took her to the first ambulance, and once she joined them back, Ljuba's friends in the bus started singing " 0 , Croatian mother, do not be sad». To which she responded : "I am not sad, my children, I am not sad. For freedom of my beloved Croatia I am ready to walk into death. And I would be happiest, if I could give my life for her ${ }^{62}$. This is the way in which Catholic Glas Koncila writes in September 1990. To the outbreak of the Yugoslav war and the moment when Ljuba would have a chance to fulfil her biggest wish, only a few months had to pass by. 


\section{NOTES}

1. Quotations and pictorial details from Glas Koncila [further in text GK], 23/10.6.1990, p. 8.

2. Ramet (Pedro), Cross and Commissar. The Politics of Religion in Eastern Europe and the USSR, Indiana University Press, Bloomington and Indianapolis, 1987, p. 3.

3. Idem, p. 103.

4. Ibid., p. 101.

5. Ivica Ra an, as quoted by ibid., p. 105.

6. Ivan Cvitkovi\}, as quoted by ibid., p. 105.

7. Ibid., p. 99.

8. Ibid.

9. GK was started in 1962, and in 1995 it reached the circulation of 50000 copies (Boeckh (Katrin), « Die Darstellung von Religion und Nation in "Glas koncila" », in Bremer Thomas, Hrsg., Religion und Nation im Krieg auf dem Balkan, Bonn, 1996, p. 127). This makes GK the most widely read among more than 100 publications of the Catholic Church in Yugoslavia. For purposes of comparison, next to 102 catholic publications, there were 16 orthodox and 6 muslim publications in Yugoslavia.

10. I am aware that such analysis will not offer a complete picture of the attitude of the Croatian Catholic Church to the Croatian national question, since it is confined to only one type of sources. I do hope, however, that the most important trends will become evident even from such a limited endeavour. In order to make my case stronger, I will offer a number of quotations and reports as delivered by GK in the analysed period which together should produce a meaningful and coherent story.

11. GK, 1/6.1.1985.

12. GK, 39/29.9.1985.

13. GK, 4/27.1.1985.

14. GK, 7/17.2.1985.

15. GK, 2/13.1.1985.

16. GK, 3/20.1.1985.

17. An article in GK 45/10.11.1985 describes a survey which was conducted among « the youth in the entire homeland ». This " youth in the entire homeland » talks in return about « our Volk» in « our Church » which ends up being Croatian Catholic Church.

18. In an article in GK 2/13.1.1985 where at the beginning we read about "mother tongue ", around the middle of the article this label changes smoothly into « Croatian language ».

19. GK, 4/27.1.1985.

20. GK, $4 / 24.1 .1988$.

21. GK, 7/17.2.1985.

22. GK, 3/17.1.1988.

23. GK, $18 / 1.5 .1988$.

24. GK, $19 / 8.5 .1988$.

25. GK, 20/15.5.1988.

26. GK, 19/8.5.1988.

27. GK, 9/28.2.1988.

28. Around the same time, Cardinal Kuhari\} in Zagreb could only mildly insist that «all nations want in their consciousness and history to be happy, living in peace and freedom, developing their identities and sovereignty equally with other nations ». GK, 4/24.1.1988.

29. GK, 21/27.5.1990.

30. GK, 5/4.2.1990. 
31. GK, 7/17.2.1985.

32. GK, 8/24.2.1985.

33. GK, 8/21.2.1988.

34. GK, 6/11.2.1990.

35. GK, 40/2.10.1988.

36. Both quotations, GK, 22/29.5.1988.

37. Both quotations, GK, 15/10.4.1988.

38. GK, 11/18.3.1990.

39. GK, 44/4.11.1990.

40. GK, 31/5.8.1990.

41. GK, $11 / 18.3 .1990$.

42. GK, 19/13.5.1990.

43. Until that point, this topic was discussed less frequently. It was mentioned in an article about the destiny of Croatian children in Herzegovina who had to learn the Cyrillic alphabet (GK, 5/4.2.1990) and in an essay about the Croatian children in Glina (a city in Croatia which up until 1995 had a significant proportion of the Serbian population) who allegedly learned history from Serbian text-books (GK, 15/15.4.1990).

44. GK, 19/13.5.1990.

45. GK, 31/5.8.1990.

46. GK, 13/1.4.1990. Today we know that ^ubrilovi\}'s gun was not real but an imitation. Drago Krpina, who disarmed $\wedge$ ubrilovi\}, claimed at the time that the gun was real, while the police asserted that it was a replica. GK observed that this case manifested that «one has to communicate with the police only in front of the witnesses and in the presence of one's lawyer ". Many years later, even Krpina acknowledged that the gun was a fake.

47. GK, 22/3.6.1990.

48. GK, 43/28.10.1990.

49. GK, 34/26.8.1990.

50. GK, 35/2.9.1990.

51. GK, 35/2.9.1990.

52. GK, 43/28.10.1990.

53. There was an echo of the official discourse in GK, too. In 1985 we find a letter by a reader asking : " Can an idea and a delusion of some members of one nation, in one tragic moment, be a permanent reason for disunity in that nation? (...) If we have reconciled with those who, as conquerors, provoked antagonism between our peoples, I see no reasons why we, as victims of that conflict, would not reconcile among ourselves. (...) It should be recognised that national reconciliation is a precondition for peaceful cooperation with other nations, because a nation which is conflicted within, cannot work on brotherhood with other nations ». GK, 1/6.1.1985.

54. GK, 17/29.4.1990.

55. GK, 28/15.7.1990.

56. GK, 45/11.11.1990.

57. GK, 45/11.11.1990.

58. GK, 37/16.9.1990.

59. Quotations and details, GK, 37/16.9.1990.

60. GK, 40/7.10.1990.

61. GK, 47/25.11.1990.

62. The whole episode in GK, 37/16.9.1990. 
INDEX

\section{Geographical index: Croatie}

Mots-clés: Deuxième Guerre mondiale, église catholique croate, nation, Glas Koncila

\section{AUTHOR}

MAJA BRKLJAČIĆ

Central European University - Budapest 